\title{
BMJ Paediatrics Open \\ Child health in Scotland: getting it right for every child?
}

\author{
Stephen Turner (1) , Samir Ahmed
}

To cite: Turner S, Ahmed S. Child health in Scotland: getting it right for every child? BMJ Paediatrics Open 2019;3:e000420. doi:10.1136/ bmjpo-2018-000420

- Additional material is published online only. To view, please visit the journal online (http://dx.doi.org/10.1136/ bmjpo-2018-000420).

Received 19 July 2019 Revised 4 December 2019 Accepted 6 December 2019

Check for updates

(C) Author(s) (or their employer(s)) 2019. Re-use permitted under CC BY-NC. No commercial re-use. See rights and permissions. Published by BMJ.

Child Health, University of Aberdeen, Aberdeen, UK

Correspondence to Professor Stephen Turner; s.w. turner@abdn.ac.uk
Many governments around the world have had different policies aimed at improving child health, but which policies are most effective? Here we propose that there is potential to understand how UK government policy can benefit child health by using robust methodologies ${ }^{1}$ to evaluate the impact of the 1999 devolution of government in the UK. Since 1999, the National Health Service (NHS) in Scotland and the NHS in England have taken slightly different routes to deliver healthcare. Perhaps the most striking difference is that there is an internal market in NHS England but not in Scotland, meaning that English hospitals are in direct competition with each other for the funding that accompanies provision of patient care. Have these differences in strategy led to differences in health outcomes?

The NHS was formed in 1948, and since then, the health of infants, children and young people in the UK has improved dramatically. Despite being an income-rich country, many of UK's children continue to face significant health challenges. Compared with our continental neighbours, childhood mortality ${ }^{2}$ and obesity ${ }^{4}$ in the UK are already, or will soon be, among the worst in Western Europe. For example, girls born in the UK in 2015 had the lowest life expectancy across Europe. ${ }^{5}$ Compared with Sweden, there are approximately 100 excess deaths per annum in children and young people in the UK. ${ }^{3}$

Poverty remains the biggest determinant of child health and well-being in the UK. ${ }^{6}$ Economic policy can directly reduce poverty. Social policy can mitigate against the link between poverty and poor health by delivering state-funded healthcare, school meals, housing, education and, where required, material goods such as clothing. In 2000, just after devolution, 32\% of children in England and Scotland were living in households whose income was below the national average. ${ }^{7}$ By 2018, a gap had emerged with the proportion remaining unchanged in England but falling to $24 \%$ in Scotland. ${ }^{7}$ Despite this apparent benefit of reduced exposure to poverty in Scotland, inequalities in health outcomes are ongoing, and life expectancy can differ by more than 20 years for people living in the least and most deprived communities. ${ }^{8}$

A non-systematic and exploratory approach to quantifying and qualifying legislation and strategies passed by governments in Westminster and Holyrood since 1999 reveals no substantial difference in the laws passed (online supplementary table 1) but difference in the quantity of strategies (online supplementary table 2) and also differences in the content of strategies. A forensic qualitative assessment of the strategies from Westminster and Holyrood is beyond the remit of this editorial, but a few observations can be made:

1. Strategies to support families in England appear to have a focus on families who are in difficulty (eg, Troubled Families Programme 2012-15), whereas in Scotland, the focus is on all families (eg, 'National Parenting Strategy: Making a Positive Difference to Children and Young People Through Parenting' (2012)).

2. Scottish Government strategies tend to more specifically promote healthy behaviours, for example, the cycling action plan and the national walking strategy.

3. Safeguarding strategies were introduced earlier in Scotland (eg, 'It's Everyone's Job to Make Sure "I'm Alright"' (2003), 'Protecting Children and Young People: The Charter' (2004) and 'Getting It Right for Every Child' (2008)). In contrast, the first comparable English strategy was launched in 2010 (Sex and Violence: Improving Your Care). Scotland has recently passed equal protection legislation (the 'antismacking law'), and there is currently no equivalent in England.

4. There are more mental health strategies in Scotland than England specifically for children and young people (eg, Scottish 
strategies in 2005, 2006 and 2018, and in 2017 for England).

5. Scotland (but not England) has policies about integration of children services (eg, "Scottish Executive (2002) Planning Together: Final Report of the Scottish Integrated Workforce Planning Group', 'Exploring the Evidence Base for Integrated Children's Services' (2006) and 'Scottish Executive Education Department (2001) for Scotland's Children: Towards Better Integrated Children's Services').

The above-mentioned focus on child-related legislation and strategy is too narrow, and a formal and wider evaluation should include structural interventions of policy and strategy, ensuring that macrolevel, mesolevel and microlevel determinants are included, and those that affect children directly or indirectly.

Looking ahead, the Scottish government has set itself targets to improve child health. In 'Every Child, Every Chance: Tackling Child Poverty', ${ }^{9}$ there is a commitment to reduce relative child poverty to less than $10 \%$ by 2030 . Economic measures to achieve this goal include Best Start Grant Pregnancy, Baby Payment Scotland, and in June 2019, the poorest families received an additional $£ 10$ per week in benefits. For obesity, the Scottish government aimed to reduce prevalence by $50 \%$ by 2030 and published plans outlining ways in which this can be achieved. ${ }^{10}$ This includes restricting the in-store promotion and marketing of food high in fat, sugar or salt, addressing portion sizes and packaging information for consumers. In 2019, bans restricted the sale of highenergy drinks to individuals under the age of 16 years in the hospital, and also, local authorities were obliged to include more fruit and vegetables in school meals and less red meat.

\section{HOW DOES CHILD HEALTH IN SCOTLAND COMPARE TO THE REST OF THE UK?}

There are many indices of child health, and here we use infant mortality, obesity and child poverty since these are included in the 2017 Royal College of Paediatrics and Child Health's (RCPCH) 'State of Child Health' (SoCH). ${ }^{11}$ Infant mortality has fallen in England, Wales and Scotland since 1999, and the fall is greater in Scotland compared with England and Wales (figure 1); in real terms, the infant mortality rate fell in England and Wales from 5.4 to 4.0/1000 live births between 2000 and 2017, and the corresponding figures in Scotland were 5.6 and 3.3. Importantly, the fall has now stalled, and most recently, infant mortality has risen in England and Wales, while the same outcome is falling in most European countries. ${ }^{2}$ The apparent greater reduction in infant mortality in Scotland compared with England might be cited as evidence that economic and social policies in Scotland are more effective, but the level of evidence available is weak.

Obesity prevalence remains static across the four UK nations (figure 2), indicating that no policy has been effective in reducing obesity. As previously discussed,

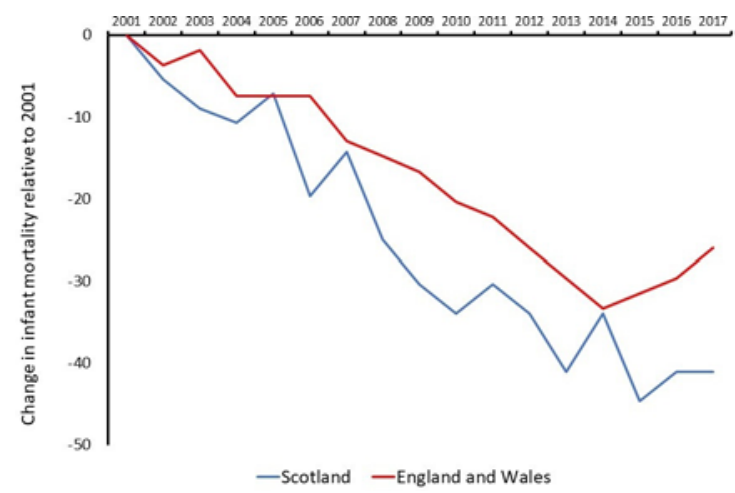

Figure 1 Percentage change in infant mortality rate in England and Wales (combined, red line) and Scotland (blue line). Data from Northern Ireland are not included since absolute number are small, resulting in considerable year-toyear variation.

child poverty has fallen in Scotland relative to England since 2000, but the proportion in Scotland rose in 2018. ${ }^{12}$

Other child health outcomes described in SoCH include sex education and reducing smoking and alcohol consumption. In Scotland, there have been reductions in parent-reported exposure to secondhand smoke (from $11 \%$ in 2014 to $6 \%$ in $2017^{13}$ ), drinking alcohol on a weekly basis (from $40 \%$ to approximately $14 \%$ between 2002 and $\left.2014^{14}\right)$ and teenage pregnancies $(61 \%$ reduction in pregnancies in under 16-year-olds since $2007^{15}$ ). Improving asthma outcomes is also an outcome in SoCH, and hospital admissions for asthma are falling in Scotland. ${ }^{16}$

The title of the Scottish government's 2008 strategy, 'Getting It Right For Every Child', epitomises what should be the goal of every government. The Scottish government is currently planning a 10-year 'Child, Young People and Families Well-being Outcomes Framework' and is expected to have a focus on early years, mental health and working across 'silos' that can develop within government. Poor

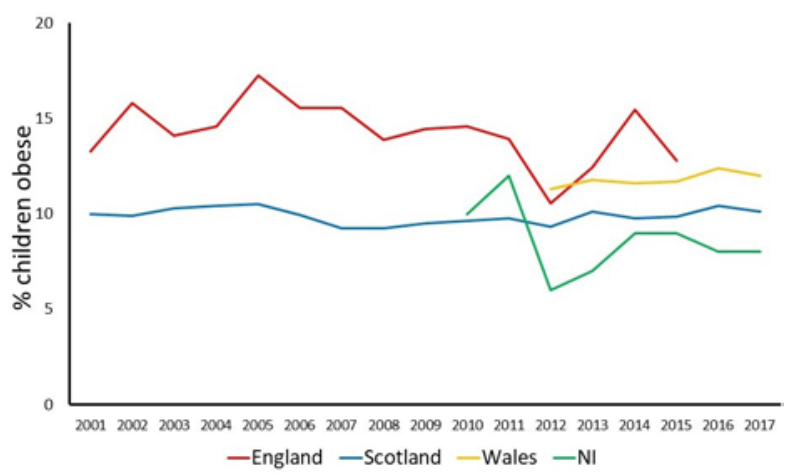

Figure 2 Trends in childhood obesity in England, Scotland, Wales and NI. The definitions of obesity used were as follows: England, >95th centile for BMI for children aged 2-10 years; Scotland, >95th centile for BMI for children aged 5-6 years; Wales, >95th centile for BMI for children aged 4-5 years; NI International Obesity Task Force definition in children aged 2-10 year. BMI, Body Mass Index; NI, Northern Ireland. 
Table 1 Suggested themes where governments, clinicians and the public could work together and examples of specific shared goals

\begin{tabular}{|c|c|}
\hline Theme & Specific goal \\
\hline $\begin{array}{l}\text { Economic } \\
\text { and social } \\
\text { policy }\end{array}$ & $\begin{array}{l}\text { Minimise the links between poverty and } \\
\text { deprivation and between poverty and } \\
\text { inequality. } \\
\text { Reduce the proportion of individuals aged } \\
18-65 \text { years who cannot work for child-onset } \\
\text { physical and mental health conditions. }\end{array}$ \\
\hline $\begin{array}{l}\text { Working } \\
\text { with } \\
\text { families, } \\
\text { children } \\
\text { and young } \\
\text { adults }\end{array}$ & $\begin{array}{l}\text { Health seeking behaviour ('when to worry' and } \\
\text { 'what to do') } \\
\text { UNCRC Article 12, respect for the views of } \\
\text { children } \\
\text { Increasing use of media to communicate, for } \\
\text { example, videoconference and live chat }\end{array}$ \\
\hline Environment & $\begin{array}{l}\text { Reduce air pollution exposures } \\
\text { Good quality housing } \\
\text { Walk to school } \\
\text { Proximity to healthy food retail outlets }\end{array}$ \\
\hline Educe & $\begin{array}{l}\text { Self awareness of mental health issues and } \\
\text { awareness of early interventions } \\
\text { Also, see 'Healthy behaviours' }\end{array}$ \\
\hline Trans & $\begin{array}{l}\text { Reduced traffic through residential areas } \\
\text { Reduced speed of traffic through residential } \\
\text { areas } \\
\text { Safer environment for pedestrians and cyclists }\end{array}$ \\
\hline $\begin{array}{l}\text { Healthy } \\
\text { behaviours }\end{array}$ & $\begin{array}{l}\text { Continue initiatives to reduce smoking and } \\
\text { intake of alcohol and high-sugar content } \\
\text { foods. } \\
\text { Promote and facilitate exercise. }\end{array}$ \\
\hline Workforce & $\begin{array}{l}\text { A modest increase in the number of } \\
\text { paediatricians } \\
\text { Closer working across primary and secondary } \\
\text { care } \\
\text { Child health as an essential component of } \\
\text { primary care training } \\
\text { Train advanced nurse practitioners and } \\
\text { physician assistants in all areas of paediatrics. }\end{array}$ \\
\hline Data & $\begin{array}{l}\text { Predict and be prepared for peaks of activity. } \\
\text { Learn from what works well in one region } \\
\text { ('atlas of variation'). } \\
\text { Child death review }\end{array}$ \\
\hline
\end{tabular}

UNCRC, United Nations Convention on the Rights of the Child.

mental health and poor physical health are end points to a pathway that includes housing, transport, education, law and order, and poverty, so the route to better health and resilience in children needs children to be considered in all aspects of government and not just health strategy. Table 1 lists areas where cross-departmental action is needed in Scotland and elsewhere.

\section{STATE OF CHILD HEALTH}

The SoCH report described 25 measures of the health of children and described outcomes where improvement is required (eg, child deaths, asthma, diabetes and

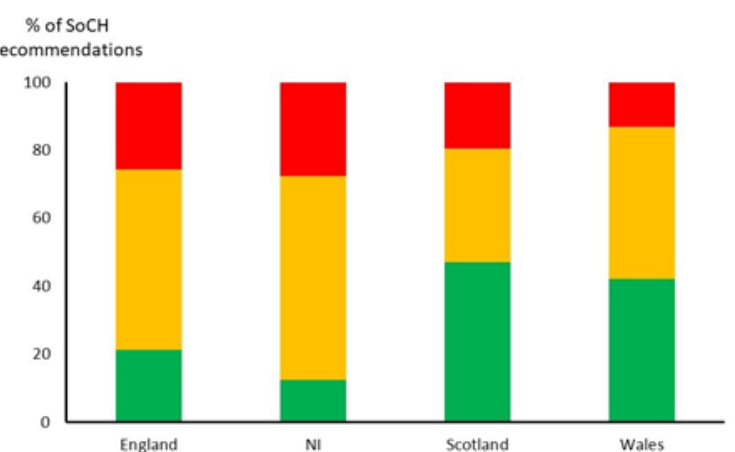

Figure 3 Bar chart displaying the proportion of recommendations made by the Royal College of Paediatrics and Child Health in the $2017 \mathrm{SoCH}$, where there had been no change (red), limited progress (amber) and significant progress (green) made by 2019. $\mathrm{NI}=$ Northern Ireland; $\mathrm{SoCH}$, State of Child Health.

epilepsy), risk factors for poor health (eg, obesity and a low rate of breast feeding) and infrastructure (eg, data, research activity). Specific examples of recommendations were

- To reduce the number of child deaths, 'The Scottish Government should implement a robust, consistent child death review system for Scotland by 2018' (there are two additional recommendations to achieve this goal).

- To tackle childhood obesity effectively, 'The Scottish Government should set challenging targets to reduce the proportion of children who are overweight or obese' (there are four additional recommendations to achieve this goal).

The recommendations made in 2017 were revisited in 2019. Figure 3 summarises the results of the 2019 'report card' of each of the four UK nation governments. Significant progress had been made on more than $40 \%$ of the recommendations to the Scottish and Welsh governments, and this proportion was $21 \%$ and $13 \%$ for England and Northern Ireland. Despite this favourable score card, there is a long way for the Scottish government to go to achieve improved child health.

\section{FACING THE FUTURE IN 2030 AND 2040}

In 2030, many outcomes of child health in the UK will be the worst in Europe, including the commonly used indices of death and obesity. ${ }^{17}$ Looking even further ahead, the RCPCH's Paediatrics 2040 project $^{18}$ is using routinely acquired data from the four UK nations to project what the prevalence of conditions affecting children and young adults will be and how the healthcare service and workforce would need to be redesigned.

The natural experiment of devolution in the NHS offers fertile ground for research to evaluate and learn from the impact of government strategy on child health. Such research could consider the following:

1. Consider all and not just the child health-focused government legislation and strategies. 
2. Use robust methodology and explore whether there is concordance in outcomes after similar interventions in different devolved nations.

3. Consider a focus on the impact of poverty on child health outcomes and how this changes over time ${ }^{19}$ especially in the context of interventions aimed at reducing poverty and disadvantage.

Contributors The concept was provided by the commissioning editor. ST and LS wrote the first draft; SA provided research for the paper; CB and MA provided strategic perspectives; and all authors made meaningful contributions to the final paper.

Funding The authors have not declared a specific grant for this research from any funding agency in the public, commercial or not-for-profit sectors.

Competing interests None declared.

Patient consent for publication Not required.

Provenance and peer review Commissioned; externally peer reviewed.

Open access This is an open access article distributed in accordance with the Creative Commons Attribution Non Commercial (CC BY-NC 4.0) license, which permits others to distribute, remix, adapt, build upon this work non-commercially, and license their derivative works on different terms, provided the original work is properly cited, appropriate credit is given, any changes made indicated, and the use is non-commercial. See: http://creativecommons.org/licenses/by-nc/4.0/.

ORCID iD

Stephen Turner http://orcid.org/0000-0001-8393-5060

\section{REFERENCES}

1 Medical Research Council. Using natural experiments to evaluate population health interventions, 2009. Available: https://mrc.ukri.org/ documents/pdf/natural-experiments-guidance/ [Accessed $29 \mathrm{Sep}$ 2019].

2 Wolfe I, Thompson M, Gill P, et al. Health services for children in Western Europe. Lancet 2013;381:1224-34.

3 Zylbersztejn A, Gilbert R, Hjern A, et al. Child mortality in England compared with Sweden: a birth cohort study. Lancet 2018;391:2008-18.

4 Organisation for Economic Co-operation and Development. Obesity update 2017, 2017. Available: https://www.oecd.org/els/healthsystems/Obesity-Update-2017.pdf [Accessed 20 Jun 2019].

5 The Nuffield Trust. International comparisons of health and wellbeing in early childhood, 2018. Available: https://www.nuffieldtrust.org.uk/ files/2018-03/1521031084_child-health-international-comparisonsreport-web.pdf [Accessed 20 Jun 2019].

6 Wickham S, Anwar E, Barr B, et al. Poverty and child health in the UK: using evidence for action. Arch Dis Child 2016;101:759-66.

7 Joseph Rowntree Foundation. Poverty levels and trends in England, Wales, Scotland and Northern Ireland, 2018. Available: https://www. jrf.org.uk/data/poverty-levels-and-trends-england-wales-scotlandand-northern-ireland [Accessed 25 Nov 2019].

8 NHS Health Scotland. What are health inequalities? 2019. Available: http://www.healthscotland.scot/health-inequalities/what-are-healthinequalities [Accessed 29 Sep 2019].

9 The Scottish Government. Every child, every chance: tackling child poverty delivery plan 2018-2022, 2018. Available: https://www.gov. scot/publications/child-chance-tackling-child-poverty-delivery-plan2018-22/ [Accessed 20 Jun 2019].

10 The Scottish Government. A healthier future: Scotland's diet and healthy weight delivery plan, 2018. Available: https://www.gov.scot/ publications/healthier-future-scotlands-diet-healthy-weight-deliveryplan/ [Accessed 20 Jun 2019].

11 Viner RM, Arkell EK, Ashe M, et al. Responding to the changing burden of disease for children and adolescents in modern Britain: the RCPCH state of child health report 2017. BMJ Paediatr Open 2017:1:e000026.

12 Scottish Government. Child poverty update, 2019. Available: https:// www2.gov.scot/Resource/0054/00546979.pdf [Accessed 29 Sep 2019].

13 The Scottish Government. Scottish health survey 2017, 2017. Available: https://www.gov.scot/publications/scottish-health-survey2017-volume-1-main-report/pages/62/ [Accessed 20 Jun 2019].

14 World Health Organisation. Adolescent alcohol-related behaviours, 2018. Available: http://www.euro.who.int/ data/assets/pdf file/ 0007/382840/WH15-alcohol-report-eng.pdf [Accessed 20 Jun 2019].

15 Scottish Public Health Observatory. Sexual health: teenage pregnancy, 2018. Available: https://www.scotpho.org.uk/behaviour/ sexual-health/data/teenage-pregnancy/ [Accessed 20 Jun 2019].

16 Al-Mahtot M, Barwise-Munro R, Wilson P, et al. Changing characteristics of hospital admissions but not the children admitted-a whole population study between 2000 and 2013. Eur J Pediatr 2018:177:381-8.

17 Royal College of Paediatrics and Child Health. Child health in England in 2030: comparisons with other wealthy countries, 2018. Available: https://www.rcpch.ac.uk/resources/child-health-england2030-comparisons-other-wealthy-countries [Accessed 20 Jun 2019].

$18 \mathrm{RCPCH}$. About our paediatrics 2040 project, 2019. Available: https:// www.rcpch.ac.uk/work-we-do/paediatrics-2040/about [Accessed 20 Jun 2019].

19 Taylor-Robinson D, Lai ETC, Wickham S, et al. Assessing the impact of rising child poverty on the unprecedented rise in infant mortality in England, 2000-2017: time trend analysis. BMJ Open 2019;9:e029424. 